\title{
THE REPUBLIC OF KAZAKHSTAN: INITIATOR OF THE ORGANIZATION OF TURKIC STATES
}

\section{Teoman Ertuğrul TULUN}

\section{Analyst}

The Cooperation Council of Turkic Speaking States (Turkic Council) was founded on October 3, 2009, in Nakhchivan as an international organization to promote comprehensive cooperation among the Turkic States. The Republic of Kazakhstan is among the founding members of this Organization, which developed to be a beacon value for the Turkic world.[1] As a matter of fact, the founder and first President of the Republic of Kazakhstan, Nursultan Nazarbayev, is the visionary statesman who put forward the idea of the Turkic Council and helped to bring it to the international platform as an organization. In this context, it is worth mentioning that Kazakhstan, in the leadership of President Nazarbayev, is also the founding father of the Conference on Interaction and Confidence-Building Measures in Asia (CICA), which is another valuable intergovernmental forum for enhancing cooperation towards promoting peace, security, and stability in Asia.

The founding members of the Organization of Turkic States are Azerbaijan, Kazakhstan, Kyrgyzstan, and Turkey. During the 7th Summit held in Baku in October 2019, Uzbekistan joined the Organization as a full member. During the 6th Summit held in Cholpon-Ata, Kyrgyzstan in September 2018, Hungary gained observer status, and Turkmenistan, during the 8th Summit held in Istanbul in November 2021.

According to its fundamental documents, the Nakhchivan Agreement of 3 October 2009 and the Istanbul Declaration of 16 September 2010, the member states of the Organization have adopted the purposes and principles of the United Nations Charter as well as other universally recognized principles of international law. International norms regarding the maintenance of peace and security and the development of good neighborly relations form the basis of cooperation to be carried out under the umbrella of the Turkic Council. 
In the preamble of the Nakhchivan Agreement, the member states affirmed their commitment to the purposes and principles of the United Nations Charter. They defined the Organization's primary purpose as deepening comprehensive cooperation among the Turkish States and contributing to regional and global peace and stability. Member states have also expressed their commitment to fundamental principles such as democracy, respect for human rights, the rule of law, and good governance. Cooperation within the scope of the Organization is built on the basis of the special solidarity between the member states arising from the common history, culture, identity, and linguistic unity of the Turkic-speaking peoples.

The main objectives and duties of the Organization set out in Article 2 of the Nakhchivan Agreement are as follows:

- Strengthening mutual trust between the parties;

- Maintaining peace in the region and outside the region;

- Adopting common positions on foreign policy issues;

- Coordinating actions to combat international terrorism, separatism, extremism, and cross-border crime;

- The development of effective regional and bilateral cooperation in all areas related to common goals;

- Creation of favorable conditions for trade and investment;

- Aiming at comprehensive and balanced economic growth, social and cultural development;

- Discussion of the rule of law, good governance and protection of human rights;

- Expanding interaction in the fields of science, technology, education and culture;

- Promoting interaction and more intensive communication with the mass media;

- Promoting information exchange and judicial cooperation on legal matters.

The Organization of Turkic States was founded in November 2021 in the Turkic Council's 8th Summit in Istanbul. The name of the Cooperation Council of Turkic Speaking States (Turkic Council) has been changed to the Organization of Turkic States. In this context, it is possible to say that the Organization of Turkic States has been the culmination of the "Heads of State Summits of Turkish Speaking Countries" since 1992. During this process, ten summits were held. At the Summit held in Istanbul on September 16, 2010, the establishment of the Turkic Council was officially announced, its priorities and roadmap were set, and the permanent structure of the Organization was declared. In addition, the name of the summits was changed to the Turkish States Summits. As stated above, this 
valuable platform has turned into a full-fledged organization in Istanbul in 2021.

As can be understood from the explanations above, Kazakhstan is a distingushed member of the Organization of Turkic States. The stability and peace of Kazakhstan is of foremost importance not only in the context of Central Asia but also in terms of security and stability for the Turkic world. In this context, the developments that caused turmoil in Kazakhstan are closely followed by the Organization of Turkic States. As AViM, we have full confidence in the common sense of the people of Kazakhstan. We wish that the coming days will bring peace, tranquillity, and stability to Kazakhstan.

*Photo: https://tr.wikipedia.org/

[1] In the following document, the Turkic Council is referred as the brainchild of President Nazarbayev. Statement on Granting the First President of the Republic of KazakhstanElbasy, H.E Nursultan Nazarbayev, the Status of the Life-Time Honorary President of the Turkic Council (Organization of Turkic States, May 24, 2019), https://www.turkkon.org/en/haberler/statement-on-granting-the-first-president-of-therepublic-of-kazakhstan-elbasy-he-nursultan-nazarbayev-the-status-of-the-life-timehonorary-president-of-the-turkic-council_1830.

About the Author:

Teoman Ertuğrul Tulun is an analyst at Ankara-based think-tank Center for Eurasian Studies. He is a PhD Candidate at Bilkent University Department of Political Science and Public Administration. His area of research include European Union Studies, Social Movements, Xenophobia and Hate Speech Studies and State Building Studies.

To cite this article: TULUN, Teoman Ertuğrul. 2022. "THE REPUBLIC OF KAZAKHSTAN: INITIATOR OF THE ORGANIZATION OF TURKIC STATES." Center For Eurasian Studies (AVIM), Commentary No.2022 / 2. January 06. Accessed January 07, 2022. https://avim.org.tr/en/Yorum/THE-REPUBLIC-OFKAZAKHSTAN-INITIATOR-OF-THE-ORGANIZATION-OF-TURKIC-STATES

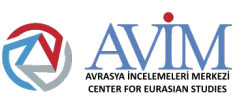

Süleyman Nazif Sok. No: 12/B Daire 3-4 06550 Çankaya-ANKARA / TÜRKIYE

Tel: +90 (312) 43850 23-24 • Fax: +90 (312) 4385026

@avimorgtr 
fftps://www.facebook.com/avrasyaincelemelerimerkezi

E-Mail: info@avim.org.tr

http://avim.org.tr

(C) 2009-2021 Center for Eurasian Studies (AViM) All Rights Reserved 